\title{
Ambassador of Lifelong Learning/ Public Libraries in Multicultural Society: The Case of Pakistan
}

\section{Yaşam Boyu Öğrenme Elçisi/ Çok Kültürlü Bir Toplumda Halk Kütüphaneleri: Pakistan Örneği}

\section{Faiza Bashir*}

\begin{abstract}
Cultural diversity is an asset, an added value, and an opportunity. Public libraries promote cultural diversity and intercultural dialogue. They play dynamic roles as social meeting places. Public libraries in a culturally diverse society work as mediators between society, culture and users. Pakistani community is a mixture of different languages and cultures which have different dimensions' and local cultural roots. This present research aims to draw a real picture of public library's role in the multicultural and digital society of Pakistani. The role of public libraries can be very vital. They can play a critical part in advocating multiplicity responsiveness, as they are responsible to provide resources to the public. They provide help and guide general public to accomplish the objective of social and monetary fairness and equity that at last will prompt a peaceful \& flourishing society. To get the maximum benefits from the cultural awareness programs devoted efforts, sufficient funds, adequate training and total commitment are required from the top management to low management of public libraries of Lahore. Public libraries can play essential role to overcome the cultural gap in Pakistani society. The work serves as a source to develop concepts and best practices of multicultural library work for all librarians concerned with these issues. It will provide an opportunity for professionals, students, and library members to create new awareness and practice.
\end{abstract}

Keywords: Lifelong learning: public library; cultural diversity; Pakistan.

$\ddot{O}_{z}$

Kültürel çeşitlilik bir kazanç, katma değer ve firsattır. Halk kütüphaneleri kültürel çeşitliliği ve kültürlerarası diyaloğu teşvik eder. Sosyal buluşma yerleri olarak dinamik bir role sahiptirler. Kültürel çeşitliliği olan bir toplumdaki halk kütüphaneleri, toplum, kültür ve kullanıcılar arasında arabulucu işlevini görürler. Pakistan toplumu, farkl boyutları ve yerel kültürel kökleri olan farklı dil ve kültürlerin bir karışımıdır. Bu araştırma, Pakistan'ın çok kültürlü ve dijital toplum yapısı içerisinde halk kütüphanesinin reel durumunu resimlemeyi amaçlamaktadır. Halk

\footnotetext{
*Assistant Professor, Government College for Women, Township, Lahore, Department of Library Science. E-mail: faizavirgo@yahoo.com

Dr. Öğretim Üyesi, Devlet Kıъ Koleji Kütüphanecilik Bölümü
}

Geliş Tarihi - Received: 21.07.2020

Kabul Tarihi - Accepted: 22.09 .2020 
kütüphaneleri önemli düzeyde hayati role sahip olabilmektedir. Genel olarak kamuya kaynak sağlamaktan sorumlu oldukları için, çok çeşitli toplum katmanlarına karşı duyarlıllğ̆ savunma bağlaminda kritik bir rol oynayabilirler. Nihai olarak barış̧̧l ve gelişsen bir toplumu harekete geçirecek olan sosyal ve mali adalet ile eşitlik hedefine ulaşmak üzere halka yardım ve rehberlik ederler. Kültürel farkındalık programlarından maksimum yararı sağlamak için özverili çabalar, yeterli fon, yeterli eğitim ile beraber Lahor'daki halk kütüphanelerinin üst düzey yönetiminden alt düzey yönetimine kadar tümünün kararl olmasl ve sorumluluk yüklenmesi beklenmektedir. Halk kütüphaneleri Pakistan toplumundaki kültür farklllıklarının yarattı̆ğ sorunların üstesinden gelmek için önemli bir rol oynayabilir. Çalışma, çok-kültürlü kütüphane konusuna ilişkin kavramlar ve en iyi uygulamaları gelişstirmesi bağlamında bu konularla ilgilenen tüm kütüphaneciler için bir kaynak işlevi görmekte olup, meslek üyeleri, ögrrenciler ve kütüphane üyeleri için yeni farkındalık ve uygulamalar yaratması anlamında bir firsat sağlayacaktır.

Anahtar Sözcükler: Yaşamboyu ögrenme: halk kütüphanesi; kültürel çeşitlilik; Pakistan.

\section{Introduction}

The perception about the role of Public libraries in Pakistani society is rapidly changing and quite different as compare with the past glory. The services and position of these libraries taken for granted in Pakistani society these days. There is misconception and ambiguity regarding the value of public libraries in Pakistani society. Due to the globalization and advancement of technology many questions raised on their existence in society, as these libraries still focus on physical services. There is a raising demand to do more for the positive contribution towards society from these libraries. Public libraries are answerable for the amount spent on them. In developing countries like Pakistan with low economy, this validation is more crucial. In this changing environment, there is emergent need for public libraries in Lahore to show their worth, both in economical as well as sociological sense.

Chandio (2012) believes that the culture of Pakistani society is a mixture of an assortment of diverse ethnic communities. This culturally diverse community based on Punjab, Baluchistan, Sindh, KPK areas which have their own history of cultural groups. Lahore being one of the largest and well populated cities has special attractions in term of cultural as well as archaeological heritage. In this context, there is a need to conduct a pragmatic study to determine the current scenario of public libraries of this culturally diverse community to determine whether they are representative of Pakistan's culturally diverse communities or not.

The objective of this present research study is to draw the actual picture of public libraries in Lahore with reference to the services and collections provided by these libraries to fulfill the multidimensional information and recreational needs of the society.

\section{Research Objectives}

The purpose of the study was to investigate the availability of multicultural literature in selected public libraries of Lahore. Lahore is a multicultural city, where people come all around the country as well as world. To highlight the core elements required for the implementation of public library services in multicultural society was another objective of the present study. 
The article also examines the meaning of cultural diversity in the library and information field, and the presumption of this multicultural reality with reference to the public library services in Pakistan. Finally, practical recommendations based on already implemented best practice are made, these may assist public libraries in Pakistan to move towards a more equitable and representative approach in the collections and services they offer their diverse constituencies.

\section{Review of Relevant Literature}

Lifelong Learning (LLL) is not a new phenomenon. LLL roots back almost a century, between 1920 s \& 1930s. At that initial stage it was only related to education and training opportunities for adults. (Vargas, 2014) What is actually mean by LLL, a very comprehensive definition is provided by the Commission of the European Communities (2001) is that LLL is "all learning activity undertaken throughout life, with the aim of improving knowledge, skills and competences within a personal, civic, social and/or employment-related perspective." Information world is becaming complex day by day, and it became very difficult to manage and fill the information gap created by the information flood. According to Fischer (2000) "Lifelong learning is an essential challenge for inventing the future of our societies; it is a necessity rather than a possibility or a luxury to be considered".

According to William F. Poole (1987), who was the first head of the Chicago Public Library "to meet the assorted needs of the library users there is a dire need to improve library collections according to the information needs of the future users".

IFLA/ UNESCO (1994) Manifesto for public libraries provides a comprehensive definition for public libraries; this manifesto believes that public library system is a spiritual force for every field of life. Public libraries system work as mediator between the fostering of harmony and progress all the way through the minds of male and female members of the society. Public libraries are mediators between all kind of information and its users. These libraries provided information needs of its users of all kind regardless of any individual identities.

According to Woodrum (1989) that the foundational task of the public libraries is to provide required information through all the possible ways and fulfill the required information needs with least resources in term of time and money (p. 132).

Nash et al (2019) mentioned that there is a need to enhance the educational initiatives for the development of lifelong learning of students. He further explores that that these skills play vital role in students learning outcomes. Peters and Romero (2019); Sun, Siklander and Ruokamo; 2018; Maynard, Simpson, and Hill; 2018 and Weisskirch; 2018) believed that the digital revolution have a deep impact on education at all levels. These learning devices create opportunities for students to get motivated for lifelong learning and joy of learning.

The core aim of the libraries was preservation in ancient times with the common approach that the large collection is the best one and in ancient public libraries was not circulated outside the library building as general rule. The librarians were not concerned about the use of 
library material but these phenomena changed in $19^{\text {th }}$ century and libraries realized that the collection is for users (Ameen, 2005).

Public libraries initiated to introduce new services trends to its users in twentieth century; accordingly, these libraries start focusing user-oriented collection. Public libraries have experienced sensational changes in twenty first century because of dramatically change in technology which make it very hard for public libraries to fulfill all the information needs of its multidimensional users with limited financial resources.

The concept of a modern public library originated in Europe in the mid nineteenth century and was spread to other parts of the world later. Great Britain is considered to be the pioneer in the modern library legislation and public library development. Chelliah (2014) believes that public library should try to reach out its multicultural users of society. He suggests that public libraries should adopt the marketing techniques for this purpose.

Ying (n.d.) suggests some marketing techniques for these libraries; he said that they can capture new users by offering unique library services or facilities i.e. maximize the library timings, celebrations of local holidays etc.

Cloete, Jacobs and Rodrigues (2006) believe that the present skills of library professionals of public libraries required more training and skills to attract new users of multicultural community. Montiel-Overall, pointed out in 2009 that library professionals need to enhance more skills for the successful launch of community programs. He believes in the shortcomings of professional skills in current library staff of public libraries.

Varheim, Steinmo and Ide (2008) explore during a study that people all over the world believes in the authenticity of information provided by the public libraries. In this regards, Norway stood first where people trust these public libraries more than any other source of information. Sweden comes after Norway because Swedish society trust on health services more than public libraries.

According to Paola (2008) public libraries are considered useful social instruments in the democratization of information; in the support of education and lifelong learning activities; in the development of personal creativity; and in the promotion of local culture. They are regarded as agents for social change. Situation regarding public libraries is quite different in Pakistani society. Most of the People are not aware of the value of public libraries for society. To get optimum benefits from the public libraries of Lahore there is an urgent need for the image building of these public libraries (Bashir, Hanif and Khanum;2018).

\section{Research Methodology}

This study is exploratory in nature. Keeping in view the objectives of the study, research design chosen for this study is largely qualitative. Patton (2002) believes that qualitative research has different objectives and approaches from quantitative research. Its aims, research methods, data collection and presentations techniques for results is also quite different from other type of research. It presents ideas through textual data rather than numerical figures. 
To explore the current scenario of multiculturalism in public libraries of Lahore, local and international literature review \&public library staff's interviews from the city of Lahore with the help of observation technique used as data gathering method.

\section{Public Libraries and Multicultural Society}

Due to the transformation of technology and flood of information the present world converted into global world. This is a new bringing about an expanding number of individuals with multisocial characters. LaTronica (2014) believes that if people have access to public library freely, they have no need for traveling to discover new fairy lands because of the multidimensional collection of these public libraries. The only thing they need is willingness to learn.

\section{Public Library and Multicultural Environment}

UNESCO (2001) believes that regard for the decent variety of societies; resilience, discourse and collaboration, in an atmosphere of common trust and comprehension are among the best certifications of universal peace and security.

The public libraries in the society must be organized on the basis of their needs. The role of a public library in a multicultural society has been discussed in a number of documents by major bodies, both national and International i.e. UNESCO, IFLA, Council of Europe.

According to IFLA/ UNESCO Multicultural Library Manifesto (2012) public libraries in multicultural society should manage community need base collections including digital resources $\&$ e collections. The Manifesto believes that these libraries should play their role in the preservation of intellectual inheritance. The libraries serving in multicultural societies should introduce new programs for community and adopt latest marketing techniques to reach out the community.

According to Wigell-Ryynanen (2003) "Classify the types of multicultural expertise in four different ways: information skills, awareness skills, cultural skills and social skills."

\section{Public Libraries in Pakistan}

Public libraries have broad roots in the historical backdrop of Sub-Continent. At the time of Independence in 1947 due to the huge migration of people of indo-Pak especially in Punjab public libraries suffered a lot and most significant resources lost due to this migration (Anwar, 1996).

There were 12 public libraries in Pakistan before 1950. Punjab Public Library, Lahore is one of the oldest libraries in Pakistan, established around 63 years before partition. It was founded by the then Governor of Punjab Lord Charles Umpherston Aitchison in 1884 by donating the collection of 75 books from his personal library. Dyal Singh Public Library was established at Lahore in 1896 by S. Dyal Singh Majithi (Kumar, 2013).

Public libraries are called "Universities of the people" in advanced, civilized and developed societies. The current situation of public libraries in Pakistan, even in big cities like Lahore and Karachi is very disappointing and frustrating somehow. 
Lahore is a multi-ethnic city consisting of multicultural, multi linguistic, religious and social groups of people. People of Lahore are open minded, socially advanced, educated, religiously virtuous. They need media which can enrich their knowledge in multicultural scenario. The city has some public libraries in different locations of Lahore. Punjab Public library, one of the oldest libraries of Pakistan is located in Lahore, established in 1884.Dyal Singh Trust Library in pursuance of the will of late Sardar Dyal Singh Majithia established in 1908 is another oldest library of Lahore. There are some public libraries established after the birth of Pakistan in Lahore; Quide-e-Azam library established in 1984, Model Town Public library established in 1986, Defence Public library was inaugurated in 2000, Barkat Hussain Public Library 2012, Chughtai Public library 2013, LCB (Lahore Cantonment Board) Public Library inaugurated in 2014are some of renowned public libraries of Lahore. However, it is very heartbreaking to state that these libraries are not up to any standard to meet the educational, social, cultural and recreational needs of the people of Lahore. Most of these libraries are in miserable condition filled with old and outdated material. Mostly people go to these libraries for reading newspapers or fiction/ novels (Bashir,Hanif, Soroya and Khanym; 2015).

\section{Public Library in a Multicultural Society}

IFLA/ UNESCO (2006) believes that cultural variety or cross-culturalism is the backbone of our local as well as our worldwide communities.

Metropolitan Group and American Library Association in 2008 provides eight principals for public libraries to improve and build multicultural communication in which they suggest that these libraries must understand their strength and community needs. The group emphasizes the involvement of new marketing strategies to reach out the community and development of communication skills of public libraries staff.

Euler and Wilke (2009) suggested that public libraries and education sector can build strong relations to provide better services in a multidimensional society. They can involve other nonprofit organizations of their respective communities. They highlight that most of multicultural people never visited their local libraries in their whole life. So, these libraries need to do something very special to attract and capture these kinds of users. Obviously for this purpose these public libraries and their staff must have skills and full understanding of their community and the need of the community.

APLA, in 2016 suggested that to fulfill the information needs in multicultural society the staff of these libraries should have some special skills and up-to-date knowledge with full command on technology as well basic knowledge of local languages of the multicultural people.

\section{Discussion and Findings}

A society where people from different cultural groups live together is known as multicultural society. Pakistan is a multicultural society, consists of a diversity of linguistic, religious and cultural communities. Foreign language collections in Pakistani libraries are limited to English language and sometimes Hindi, Gurumukhi, German and French. The recent tends to include Chinese language. It was noted during study that public libraries of Lahore facing shortage of 
staff with multi-language abilities to hold such book collection and cataloging of various foreign/local languages material.

The IFLA/ UNESCO (1998) guidelines recommend that public libraries must hold and manage the balanced collection for their local community in their local language relating to their own cultures.

Lahore is a city situated in the northwest of Pakistan. It is the capital city of the province of Punjab and is the main center for culture in both the Punjab region and Pakistan as a whole. Lahore the $2^{\text {nd }}$ populated city of Pakistan and $42^{\text {nd }}$ most heavily populated city in the world with population of $11,126,285$. These approximate figures are the cluster of urban population of Lahore, which also includes the adjacent suburban areas. Lahore is a city rich in history and tradition; 87\% of them speak Punjabi; other languages spoken include Urdu and English. 94\% of the population in Lahore is based on Muslim; the remaining 6\% are nearly all Christians, with small number of minority religions such as Sikh and Hindu. With less than $40 \%$ of the population of the city are literate (World Population Review,2018).

Result of study reveals that in public libraries of Lahore the purchase ratio of Urdu language books was high in compression with English and other languages. Approximately 60\% of purchase titles were in Urdu language followed by the English language. The ratio of other languages (Arabic, Persian, Sansikrat, Punjabi, Hindi etc.) was less than 1\%. In these libraries' preference given to the subject of literature and most books were acquired in this specific subject area. Urdu literature given more preference as approximately $75 \%$ books were related to Urdu literature. Bashir, Hanif, Soroya and Khanum (2015) conducted a study to explore the major trends of purchase in public libraries of Lahore. She highlights that in public libraries of Lahore major neglected areas of purchase are art \& architecture and languages. She furtherindicates that most of public library users of Lahore were dissatisfied regarding the maintenance of equal collection of books.

It is also evident from the analysis of the data that circulation of book stock for languages other than Urdu are very low. Books being issued are largely in Urdu language followed by English. The issue ratio of books from languages other than Urdu and English is very low.

The results also show that librarians of these public libraries do not consider alternative sources of information, especially in those languages where there is a lack of published materials. Even in the age of information and communication technology (ICT) most libraries are using old methods because they do not have proper training for use of these technologies for cultural diversity of multicultural services.

Finding reveals that the staff of these public libraries believes that to provide these kinds of services they need enhanced budget.

The results of the study show the training required for the staff of these libraries and awareness in cultural diversity issues for public libraries in Lahore. The result also shows that public libraries of Lahore do not be familiar with the varied nature of their communities served by them. 


\section{Conclusion}

The veracity of a multicultural society in Lahore is a somewhat new experience which framed during the previous couple of decades. People come all around the country with different cultural values. Many of them have been living in Lahore for quite a few years. Out of them some people are aware of public libraries services; but most of them are unaware or reluctant due to certain reasons. Almost half of the population of Lahore never steps in to the public library of their city in their whole life. There are many reasons behind this phenomenon situation, but the major reason behind is that most of the people are unaware of public libraries services, it is the major tasks of public libraries to reach out the underserved prospective users. Once public libraries resolve this issue, more users will come to use the free services of public libraries.

The world turned in to global village due to the evolution of technology i.e. advancement in transportation and media transmission in the twentieth century. Without a doubt we are altogether residents of the world that comprises of every human race. We should figure out how to live gently with each other and to regard and esteem different societies as our own.

In this regard, the role of public libraries can be very vital. They can play a critical part in advocating multiplicity responsiveness, as they are responsible to provide resources to the public. They provide help and guide general public to accomplish the objective of social and monetary fairness and equity that at last will prompt a peaceful \& flourishing society.

To get the maximum benefits from the cultural awareness programs devoted efforts, sufficient funds, adequate training and total commitment are required from the top management to low management of public libraries of Lahore.

Public libraries can play essential role to overcome the cultural gap in Pakistani society. Being professional all of us should participate in such activities and enhance these efforts to ensure that we are sensational members of our varied society. We hope that Public library users and professional organizations as well as Government bodies will join their hands to close the cultural gap and take advantage of free multicultural resources and the expert guidance of librarians.

\section{Recommendations}

- Public Libraries should try endeavors to hire staff with multi-language abilities to deal with these multi-lingual materials and provide better services to its users.

- Due to the rapidly increasing multicultural society it is very difficult for public libraries to satisfy all the multicultural users especially as they have extensive variety of branch of knowledge with restricted budget. So, there is a need for introducing the concept of rotating collection in public libraries of Lahore. These multi lingual books will rotate after four to six months from one library to another.

- There is a need to provide a multi-lingual on-line catalog in public libraries of Lahore. Punjab public library holds the biggest multi-lingual collection among all the libraries of Lahore so it can take the responsibility to manage this on-line multi-lingual catalog. 
- Public libraries should make a combined effort for the recruitment of staff with multilingual abilities. Punjab Government played a main part by offering grant to empower brilliant young fellows and ladies of social minorities to go to universities and colleges in Punjab through allocated quota. Here is need to encourage these students to join the library profession.

- Public libraries of Lahore should launch the Diversity Awareness Program for its staff and provide training through diversity workshops. With the help of Cultural diversity workshops library staff learns the most effective method to help users with dialect issue; it makes staff more delicate towards users from multi-cultural environment and give course of action to understand these users' extraordinary requirements.

- Public libraries should display their new added collection for multicultural user's interest and arrange special exhibition on holidays to highlight these collections. Monthly publication of these newly acquired titles can be an attracting idea.

- Celebrations of cultural holidays/festivals/ exhibition make can be a brilliant idea for public libraries, attractive cultural art works, handicrafts of different cultures, artifacts, local books to place at the display with the help of cultural programs for the general public.

- Public libraries should offer bi-lingual story times to attract multicultural users which can be quite popular among new immigrants.

- Public libraries should arrange book discussions, lectures and group talks on cultural topics to share ideas and exchange precious knowledge. Books by minority authors or on different culture can be trendy amongst different age groups.

- Public libraries should adopt new marketing techniques for the better awareness of users about library multicultural collection and services.

- Public libraries of Lahore should improve their role for the literacy and lifelong development of community. 


\section{References}

Ameen, K. (2005). Developments in the philosophy of collection management: A historical review Collection Building, 24(4). 112 - 116.

Anwar, M. A. (Ed.). (1996). Public library legislation in Pakistan: Textual sources. Lahore: Library and Information Management Academy.

[APLA] Australian Public Library Alliance. Guidelines, standards and outcome measures for Australian Public Libraries. ALIA, July 2016 Retrieved from https://www.alia.org.au/node/184/publiclibraries

Bashir, F., Hanif S. S. and Khanum, A. (2018). Users' satisfaction as a valid measure for information resources: A case of public libraries. Journal of Library Administration, 58(3), 302-312

Bashir, F., Hanif S. S., Soroya, M. S. and Khanum, A. (2015). Emerging trends of acquisition in public libraries of Pakistan: challenges and issues. Collections, Acquisitions, and Technical Services, $39(1-2), 40-44$.

Chandio, A. (2012). Pakistan - A land of cultural diversity. Retrieved from http://blogs.epakistan.com/pakistan-a-land-of-cultural-diversity/ on

Chelliah, R. (2014). Community building, multiculturalism and the suburban public library. Retrieved from http://ro.ecu.edu.au/theses/1524

Cloete, L., Jacobs, L. and Rodrigues, A. (2006). Providing equitable public library services to South Africa's multicultural communities. Mousaion, 24(2), 211-231.

Commission of the European Communities. (2001). Making a European area of lifelong learning a reality. Retrieved from, https://www.europarl.europa.eu/meetdocs/committees/cult/0020122/com(2001)678_en.pdf

Euler, J. and Wilke, S. (2009). Diversity management as a key challenge to the library in the multicultural society. Retrieved from http://eprints.rclis.org/12942/1/108.pdf

Fischer, G. (2000). Lifelong learning: More than training. Journal of Interactive Learning Research, 11, 265-294.

IFLA/ UNESCO. International Federation of Library Associations. (2012). IFLA/ UNESCO multicultural library manifesto. Retrieved from http://www.ifla.org/node/8975

IFLA/ UNESCO (2006). Multicultural library manifesto and toolkit. Retrieved from https://www.ifla.org/node/8975

IFLA/ UNESCO. (1998). The public library services: IFLA/ UNESCO guidelines for development. IFLA Publication 97. Retrieved from https://www.ifla.org/files/assets/hq/publications/archive/the-publiclibrary-service/pub197.pdf

IFLA/ UNESCO Public library manifesto 1994. Retrieved from https://www.ifla.org/publications/iflaunesco-public-library-manifesto-1994

Kumar, D. (2013). Libraries in Punjab: A history of public library. Retrieved from http://www.apnaorg.com/research-papers/arjun1

LaTronica. S. (2014). Libraries working to bridge the cultural divide. Retrived from https://www.huffingtonpost.com/starr-latronica/libraries-cultural-divide_b_5241903.html

Maynard, G., Simpson, M. and Hill, R. (2018). Navigating the path to digital literacy and telehealth with final year pharmacy students. 51. poster session presented at LifeLong Learning in Pharmacy. Brisbane, Australia. Retrieved from http://pharmacyeducation.fip.org/pharmacyeducation/article/view/734/647 
Metropolitan Group and American Library Association. (2008). Increasing relevance, relationships and results: Principles \& practices for effective Multicultural Communication-Library Edition. Retrieved from https://www.metgroup.com/assets/594_mcclibv90120screen.pdf

Montiel-Overall, P. (2009). Cultural competence to create multicultural libraries. The Library Quarterly, 79(2), 175-204.

Nash, R., Chalmers, L., Stupans I. and Brown N. (2019). Developing lifelong learning skills: Using a traffic light report to promote competency standards and self-assessment among pharmacy undergraduates. In: Trimmer K., Newman T., Padró F. (Eds). Ensuring Quality in Professional Education,Human Client Fields Pedagogy and Knowledge Structures, Springer, Switzerland. V.I. p. 209-240.

Patton, M. Q. and Cochran, M. (2002). A guide to using qualitative research methodology. Retrieved from https://evaluation.msf.org/ sites/evaluation/files/a_guide_to_using_qualitative_research_ methodology.pdf

Peters, M. and Romero, M. (2019). Lifelong learning ecologies in online higher education: Students' engagement in the continuum between formal and informal learning. British Journal of Educational Technology, 50(4), 1729-1743.

Paola P. M. A. (2008). Multicultural libraries' services and social integration: The case of public libraries in Montreal Canada, Public Library Quarterly, 27(1), 41-56, DOI:10.1080/01616840802122443

Sun, L. P., Siklander, P. and Ruokamo, H. (2018). How to trigger students' interest in digital learning environments: A systematic literature review. In Seminar. net 14(1), (p. 62-84).

UNESCO Universal Declaration on Cultural Diversity 2001. Retrieved from http://portal.unesco.org/en/ev.php-

URL_ID=13179\&URL_DO=DO_TOPIC\&URL_SECTION=201.html

Vargas, C. (2014). Lifelong learning principles and higher education policies. Tuning Journal for Higher Education, 2(1), 91-105.

Varheim, A., Steinmo, S. and Ide, E. (2008). Do libraries matter? Public libraries and the creation of social capital. Journal of Documentation, 64(6), 877-892. DOI: 10.1108/00220410810912433

Weisskirch, R. S. (2018). Grit, self-esteem, learning strategies and attitudes and estimated and achieved course grades among college students. Current Psychology, 37(1), 21-27.

Wigell-Ryynänen, B. (2003). Public space for personal use: The multicultural society as the norm. Scandinavian Public Library Quarterly, 1(4), 3-4. Retrieved from http://slq.nu/wpcontent/uploads/vol36_4/splq_0403.pdf

William, F. P. (1987). The Organization and Management of Public Libraries in Public libraries in the United States: Their history, condition, and management, Part I. (p. 479-80). Washington, D.C.: Govt. Print. Off.

Woodrum, P. (Ed.). (1989). Managing public libraries in the 21st century. New York: Haworth Press.

World Population Review. (2018). Retrieved from https://worldpopulationreview.com/

Ying, H. (n.d). The role of public library in a multicultural society. Retrieved from http://wwwws.gov.taipei/001/Upload/public/Attachment/033011193386.pdf 